\title{
ZMIANY SYSTEMOWE W SEKTORZE OCHRONY ZDROWIA
}

\section{SYSTEMIC CHANGES IN THE HEALTH CARE SECTOR}

\author{
Kazimierz Dobrzański \\ Wyższa Szkoła Zarządzania i Bankowości w Poznaniu \\ emerytowany pracownik Katedry Systemów i Technik Zarządzania \\ Uniwersytet Ekonomiczny w Poznaniu
}

DOI: https://doi.org/10.20883/pielpol.2017.19

\begin{abstract}
STRESZCZENIE
Artykuł omawia proces zmian w ochronie zdrowia, ukazuje określone zależności w procesie transformacji ustrojowej i komercjalizacji oraz efekty zmian w sektorze ochrony zdrowia.

Zmiany systemowe, zauważalne w minionym i obecnym czasie, są widoczne na terenie kraju. Ich rezultaty są bardzo zróżnicowane. Zauważa się też swoisty dystans pomiędzy przebiegiem zmian a poziomem realizacji przyjętych założeń. Wyrazem powyższego są poszerzający się proces komercjalizacji oraz poszukiwanie zasadnego modelu postępujących zmian. W procesie społeczno-ekonomicznych przeobrażeń systemowych dostrzega się wiele różnych i nietypowych zjawisk, z reguły określanych przepisami prawa. Zazwyczaj te ostatnie są źródłem narastających napięć społeczno-politycznych i gospodarczych. Odnoszą się one do jednostek organizacyjnych ochrony zdrowia, ich wielkości i uprzedmiotowienia, a także zarządzania.

Proces reformowania systemu zdrowia kładzie nacisk na podmiotowość rynku ochrony zdrowia. Jednak system opieki zdrowotnej nadal wymaga przeobrażeń mających na celu eliminowanie jego słabości. Podkreśla się przy tym konieczność zapewnienia dostępności usług i świadczeń zdrowotnych na możliwie najwyższym poziomie wiedzy, sztuki medycznej i zasad dobrej praktyki. Dalszym zmianom systemu winny sprzyjać motywujące kontakty menadżerskie. Realizacja wytyczonych celów możliwa będzie dzięki różnym formom grantów, partycypowaniu w rynku usług pełnopłatnych oraz poszukiwaniu nowych środków finansowania. Analiza zasobów rzeczowych, finansowych i osobowych wskazuje na konieczność samofinansowania placówek medycznych na podstawie prowadzonego rachunku kosztów w oparciu o świadczenia publiczne i prywatne.
\end{abstract}

SŁOWA KLUCZOWE: zmiany, przeobrażenia systemowe, organizacje, ochrona zdrowia.

\section{Wprowadzenie}

Zmiany systemowe w Polsce, realizowane w minionym okresie i obecnym, zauważalne są we wszystkich dziedzinach życia gospodarczego i społecznego, aczkolwiek ich rezultaty są znacznie zróżnicowane. Dostrzega się to w postawach i zachowaniach zarówno jednostek ludzkich, jak i całego społeczeństwa, również na poziomie realizacji przyjętych założeń. Zmiany dotyczą też służby zdrowia. Urynkowienie procesu opieki zdrowot-

\begin{abstract}
This article discusses the process of changes in health care, shows the specific dependencies in the process of political transformation and commercialization, as well as the effects of changes in the health sector.

Systemic changes noticeable in the past and nowadays are visible throughout the country. Their results are very diverse. There is also a kind of discord between the course of changes and the level of implementing acquired assumptions. The expression of the above is a widening commercialization process and the search for a reasonable model of progressive changes. In the process of socio-economic systemic transformation many different and unusual phenomena, generally defined by law, are recognized. Typically, these latter are a source of growing socioeconomic and political tension. They refer to the organizational units of health care, their size, objectification, and management. The process of reforming the health care system emphasizes the subjectivity of the health care market. However, the health care system still requires transformations in order to eliminate its weaknesses. The need to ensure the availability of services and health services at the highest possible level of knowledge, medical art and the principles of good practice are emphasized as well.

Further changes in the system should promote motivating managerial contacts. Implementation of the goals will be possible thanks to different forms of grants, participating, in the fully-paid service market, and searching for the new funding. Analysis of material, financial and personal resources points to the need to self-finance medical facilities on the grounds of cost accounting based on public and private benefits.
\end{abstract}

KEYWORDS: changes, systemic transformations, organizations, health care.

nej, czego wyrazem jest postępujący proces komercjalizacji, prowadzi do poszukiwania zasadnego modelu postępujących zmian.

Proces urynkowienia w złożonych uwarunkowaniach społeczno-ekonomicznych ujawnia wiele różnych i nietypowych zjawisk określonych przepisami prawa. Szczególnie te ostatnie sąźródłem narastających napięć społecznych. Kształtują się one również w otoczeniu jednostek organizacyjnych ochrony zdrowia, a zależą od 
ich wielkości i uprzedmiotowienia oraz struktury zarządzania. W powyższym wzrasta złożoność, burzliwość i dynamiczność przeobrażeń jednostek organizacyjnych ochrony zdrowia. Tempo owych zmian i ich efektów stale wzrasta.

Jednostki ochrony zdrowia muszą efektywnie reagować na sygnały z otoczenia. Jednymi więc z podstawowych obowiązków zarządzających (kadry menadżerskiej) oraz współpracowników są analiza zmieniających się potrzeb społeczeństwa, zachowań konkurencji oraz reakcja na zmiany systemu. Od intuicji zawodowej, umiejętności przewidywania kierunku zmian oraz zaangażowania i chęci podnoszenia kwalifikacji zawodowych kadry zarządczej zależy pozycja danej jednostki na rynku usług medycznych. Stąd cele opracowania to zwrócenie uwagi na uwarunkowania i działanie czynnika ludzkiego, wskazanie na złożoność i ich rolę w organizacjach ochrony zdrowia, a też na konieczność zarządzania wiedzą i dalszą edukacją. Opracowanie to winno uzmysłowić zasadność oddziaływania na właściwe kręgi współpracowników, a też na racjonalne wykorzystanie zasobów ludzkich w usługach ochrony zdrowia.

\section{Zmiana, podstawowe pojęcia}

Współcześnie działające organizacje poddane są różnorodnym wpływom, zarówno otoczenia, jak też innych jednostek oraz relacji pomiędzy nimi. Procesy te mogą powodować kreowanie nowych pomysłów, budzić z uśpienia oraz kumulować energię. Wzrost energii jest jednym z kluczowych czynników sukcesu współczesnej organizacji, poddanej ciągłej transformacji, równie ważnym jak zarządzanie procesem zmian.

„Zmiana to dokonywanie się lub dokonanie się przeobrażeń zmieniających charakter (...), wynik przeobrażenia na lepsze, gorsze" [2]. Tak więc jedną z cech charakterystycznych współczesnego świata jest jego zmienność. Zmiany należą do zjawisk uniwersalnych, związanych ściśle z życiem i rozwojem ludzkości [3]. Zmiana przestała być traktowana jako zagrożenie, natomiast dostrzeżono w niej fundament rozwoju. Można nią pokierować stosownie do potrzeb i otoczenia w kontekście zasadniczej przewagi konkurencyjnej.

Zmiany współczesne są nie tylko dynamiczne, ale też bardziej złożone, nieciągłe, nowatorskie i kosztowne oraz trudne do przewidzenia. Podobnie powiązania pomiędzy nimi są kompleksowe i nieprzewidywalne [4].

Implikuje to konieczność fundamentalnej zmiany metod działania, jak też weryfikowania i przewartościowania osobistych założeń jednostki ludzkiej i społeczeństwa oraz kształtowania dużej elastyczności myślenia na rzecz wypracowania nowej filozofii zarządzania organizacjami i systemem ochrony zdrowia. Działając w polskich warunkach stabilnej gospodarki, zatraci- ły one w dużym stopniu zdolność do właściwego reagowania w obliczu zmian i nie posiadają w szerszym stopniu wypracowanych procedur ich wdrażania. Stąd wdrożenie nowego sposobu myślenia i stworzenie nowej orientacji okazało się procesem złożonym, bardzo trudnym i długotrwałym.

Współczesne otoczenie, definiowane jako miejsce powstawania istotnych decyzji, narzuca ograniczenia organizacji i kształtuje jej przyszłość. Aktualnie organizacja i zarządzanie podkreślają rolę środowiska - ma ono większe znaczenie dla organizacji niż dla jej reguł działania. Tworząc określone rozwiązania z kontrahentami i kooperantami, powiększyły swoje zależności od innych podmiotów, a też od otoczenia. Częste zmiany w organizacji stały się więc nieuchronne, a jednocześnie umiejętność ich przeprowadzenia jest niezwykle istotna. Zmienił się także ich odbiór. Zmiany, będąc sposobem przejścia z jednego stanu do drugiego, stanowią integralną część życia każdej instytucji i organizacji.

Restrukturyzacja, organizacja i rozwój, innowacje i transformacja - wszystkie te pojęcia odnoszą się do zmian. Rozumiane są bardzo szeroko - jako „proces uszeregowania ludzi, zasobów i kultury pod kątem przekształceń w sferze organizacyjnej" [5]. Jednocześnie zarządzanie zmianami ma urealniać w ludziach wyzwanie i siły dla realizacji zadania, jakim jest przeprowadzenie zmiany. Analizując głębokość zmian, można wyróżnić zmiany głębokie i powierzchowne, polegające na bieżącym „ulepszeniu struktur, procesów i systemów” [6].

W kategoriach ogólnych zmiana jest procesem stwierdzenia różnicy pomiędzy jednym stanem a innym bez względu na jej przyczyny, formy czy skutki. Odnosi się do dowolnego aspektu organizacji, jednocześnie wyraża się w przekształceniach podsystemów organizacji i powiązań pomiędzy nimi, a nadto do relacji między organizacją a jej otoczeniem. Natura zmian jest złożoną, jak też złożone są warunki, w których ona przebiega.

Kieruje ona uwagę ku przyszłości, czyli przenosi punkt ciężkości z bieżących uwarunkowań organizacji na jej stan przyszły [7]. Problem zmian jest jednocześnie problemem dynamiki przedsiębiorstwa w formie rozwoju, to jest reprodukcji i transformacji. Szczególnie zmiany transformacyjne, to jest wynikające z przejścia od jednej fazy rozwojowej do następnej, wymagają przekształcenia strategii organizacji. Orientując się na cel zmian, można wyróżnić pięć następujących form zmian. Są nimi:

- usprawnienie działalności bieżącej,

- $\quad$ naprawianie błędów w celu wyprowadzenia przedsiębiorstwa z niepowodzenia,

- $\quad$ konstruowanie domeny działalności (wytyczanie obszarów produkt - rynek),

- transformacja, 
- budowanie mocnych stron przedsiębiorstwa w celu tworzenia lub umacniania wyróżniającej się kompetencji [8].

Jednocześnie należy zaznaczyć, że zmiana to proces dostosowania ludzi, zasobów i kultury do zmieniającego się otoczenia biznesowego przedsiębiorstwa, jak też organizacji non-profit. W dynamicznym otoczeniu liderzy firm i instytucji odchodzą od systemu nakazu kontroli i adaptują zasady filozofii przywództwa, doradztwa i szkolenia. W efekcie całościowa odnowa organizacji koncentruje swoją uwagę na ludziach i ich zdolnościach do adaptacji nowych sposobów zachowań i efektywnych realizacji zadań. Jednocześnie jest zagrożeniem dla pracowników, środowiska pracy, jakie znają, treści i sensu wykonywanych przez nich działań i operacji. Zmiana jest więc nieuniknioną częścią życia organizacji, ma fundamentalny wpływ na jej rozwój.

\section{Zmiany w przeobrażeniu systemu zdrowia}

Zarządzanie każdą organizacją i instytucją musi być działaniem właściwie zaprogramowanym oraz umiejętnie wprowadzonym.

Kluczowym elementem tego procesu jest zarówno człowiek, jak też emocjonalne i intelektualne zrozumienie konieczności zmian. Im bardziej uda się zaangażować personel i wdrożyć mechanizmy wsparcia, tym łatwiej pokonać opory i przekształcić je w siły wspierające zmiany. Odnosi się też do przeobrażeń systemu zdrowia. Jednocześnie badanie kultury zmian oznacza umiejętność najlepszego sposobu uwrażliwienia personelu, a też wykształcenie nowych postaw i zachowań oraz przyszłości.Zdrowie można uznaćza dobro inwestycyjne i społeczne, jednocześnie stanowi ono jedno z najważniejszych potrzeb jednostki ludzkiej i społeczeństwa. Sektorem dostarczającym świadczenia zdrowotne są szeroko rozumiane służby zdrowia, udzielające jednostce pomocy. Opieka zdrowotna jest to „system usług zdrowotnych świadczonych przez zatrudniony w specjalnie do tego powołanych zakładach służby zdrowia personel, posiadający odpowiednie przygotowanie fachowe i formalne uprawnienia w celu utrzymania i poprawy zdrowia jednostek i społeczeństwa, zapobiegania chorobom, wczesnego ich rozpoznawania, leczenia i rehabilitacji oraz zwalczania ich przyczyn" [9].

W latach 80. XX wieku, w ramach rozwiązań społecznych, podjęto działania na rzecz reformy opieki zdrowotnej, czyli powszechnego dostępu do świadczeń. Stała się ona najważniejszym z filarów nowoczesnego państwa. Jednakowoż na reformę opieki zdrowotnej w tamtych latach wpływ miały znaczne ograniczenia finansowe. W kontekście powyższego podjęto stosowne działania na rzecz przeobrażeń, które wymusiły:
- $\quad$ załamanie społecznego zaufania do instytucji medycznych,

- $\quad$ przekroczenie granicy niezadowolenia wśród pacjentów i pracowników, pacjenci mieli poczucie uprzedmiotowienia, natomiast personel medyczny sfrustrowany był faktem niemożności wpływania na zarządzanie swoimi zakładami pracy,

- recesja lat 80. i 90.

Okazało się, że reforma była procesem znacznie bardziej skomplikowanym w stosunku do stosowanego modelu ekonomicznego i politycznego. Równocześnie podjęto zmiany na fali euforii związanej z wprowadzeniem zmian polityczno-gospodarczych i społecznych. Traktując reformę jak przedsięwzięcie łatwe, nie doceniono jej skali, konsekwencji i natury. Spowolniły one mechanizmy demokratyczne wdrożenia reformy, które uzależnione były od cykli politycznych, bowiem wybory parlamentarne oznaczały rezygnację z niepopularnych decyzji. Zamiast spodziewanego entuzjazmu i współpracy środowisk medycznych decydenci napotykali brak akceptacji i sprzeciw. Dodatkowo na przeszkodzie stawały niejasności koncepcyjne, a szczególnie trudność wkomponowania tworzonych mechanizmów w funkcjonujące systemy.

Lata 80. ujawniły słabość polskiej służby zdrowia. Kryzys ekonomiczny i społeczny lat 1982-92 stał się impulsem do zapoczątkowania działań reformatorskich, które katalizowały trzy podstawowe czynniki:

- dramatycznie rosnąca nieefektywność dotychczasowego systemu organizacji i finansowania ochrony zdrowia,

- $\quad$ ogromny postęp nauk medycznych i techniki zwiększający koszty leczenia i diagnostyki,

- wzrastająca różnica między oczekiwaniami pacjentów w zakresie świadczeń a poziomem oczekiwanych usług.

Jednocześnie dodatkowymi bolączkami służby zdrowia były pogarszająca się dostępność, rosnące zadłużenie, zła organizacja pracy oraz przestarzałe zaplecze techniczne. Wskutek powyższego konkurencja - podstawa gospodarki rynkowej - została stopniowa włączona w działanie sektora zdrowotnego.

Przebiegała ona wielowarstwowo. Głównymi kierunkami wdrażań były:

- dopuszczenie SP ZOZ,

- wzmocnienie roli podstawowej opieki zdrowotnej,

- $\quad$ prace zmierzające do wprowadzenia PUZ (Publiczne Ubezpieczenie Zdrowotne),

- zwiększenie roli samorządów terytorialnych w gwarantowaniu opieki zdrowotnej.

Najistotniejszym elementem procesu reformowania systemu ochrony zdrowia była Ustawa z dnia 30 sierpnia 1991 r. o zakładach opieki zdrowotnej. Zgodnie 
z nią „zakład opieki zdrowotnej był wyodrębnionym organizacyjnie zespołem osób i środków majątkowych, utworzonym i utrzymywanym w celu udzielania świadczeń zdrowotnych i promocji zdrowia" [10].

Jednocześnie zakłady opieki zdrowotnej zostały określone podmiotami prawnymi o cechach państwowej jednostki organizacyjnej, prowadziły działalność gospodarczą, udzielając świadczeń zdrowotnych, były też organizacjami non-profit.

Nadto wynikiem nowelizacji ustawy w 1996 r. uznano, że z zasady będzie to zakład samodzielny. Znalazło to swój wyraz w przepisach dotyczących m.in. zasad i form wykonywania zawodów medycznych, a też praw i obowiązków lekarzy, farmaceutów, pielęgniarek i położnych.

Przełomową datą dla systemu ochrony zdrowia, a też jednocześnie dla organizacji zdrowotnych, był 1 stycznia 1999 r. Wprowadzone i kontynuowane w latach późniejszych szerokie zmiany systemowe zapoczątkowały proces całkowitej przebudowy dotychczasowego systemu poprzez zmiany w polityce zdrowotnej państwa, tj. sytuacji pacjenta, organizacji placówek medycznych, sposobie zarządzania i statusie zawodowym pracowników służby zdrowia oraz zasadach finansowania ochrony zdrowia. Istotną byłą też Ustawa (...) o zamówieniach publicznych (Dz.U. z 2002 r. Nr 72, poz. 664, ze zmianami) [11]. Efektem powyższych rozwiązań, będących pochodną szczegółowych przepisów prawnych zawartych w Ustawie (...) o zawodach lekarza i lekarza dentysty, Ustawie (...) o zawodach pielęgniarki i położnej, Ustawie (...) o powszechnym ubezpieczeniu i Ustawie (...) o zakładach opieki zdrowotnej, były liczne przedsięwzięcia natury ogólnej i szczegółowej. Umożliwiły one rozwiązania dotyczące warunków prowadzenia prywatnej praktyki, a także określiły prawa pacjenta jako istotnego podmiotu opieki zdrowotnej i partnera lekarza w procesie świadczenia usług medycznych.

Zmiany, zasadne z punktu widzenia podmiotów leczniczych, a też oczekiwań społecznych, umożliwiły m.in.:

- dokonanie instytucjonalnego rozdziału płatnika i świadczeniobiorcy,

- formalne wprowadzenie, na zasadzie powszechnego obowiązku, ubezpieczenia zdrowotnego, dostępnego dla prawie wszystkich obywateli,

- $\quad$ uzyskanie świadczeń na zasadzie solidaryzmu społecznego,

- $\quad$ uzyskanie powszechnej samodzielności przez podmioty lecznicze,

- $\quad$ wprowadzenie systemu kontrolowania świadczeń zdrowotnych przez kasy chorych (obecnie oddziały Narodowego Funduszu Zdrowia),

- wprowadzenie instytucji lekarza rodzinnego,
- $\quad$ stworzenie podstaw konkurencji między świadczeniodawcami i kasami chorych (obecnie NFZ) [12].

Z powyższego wynika, że podmiotom leczniczym wyznacza się pierwszoplanową rolę w reformie zdrowia. W warunkach aktualnych prowadzą one specyficzną działalność na rzecz różnych podmiotów. Zgodnie z Ustawą z dnia 27 sierpnia 2004 r. o świadczeniach opieki zdrowotnej finansowanych ze środków publicznych (tekst jedn. Dz.U. z 2008 r. Nr 164, poz. 1027 z późn. zm.) działalność ta sprowadza się do profilaktyki, zachowania, ratowania, przywracania lub poprawy zdrowia oraz do innych działań medycznych z procesu leczenia lub przepisów odrębnie regulujących zasady jej prowadzenia.

Funkcjonując w warunkach rynkowych, prowadzą one specyficzną działalność na rzecz różnych podmiotów. W kontekście dokonywanych zmian można wskazać na podstawowe cechy jednostek, są nimi [13]:

„• realizowanie określonego zakresu zadań związanych z udzielaniem świadczeń zdrowotnych,

- $\quad$ skupianie potencjału osobowego i majątkowego niezbędnego do realizacji badań związanych z świadczeniem usług zdrowotnych,

- $\quad$ posiadanie względnie zewnętrznie układu organizacyjnego, właściwego dla realizacji zadań,

- posiadanie określonej samodzielności ekonomicznej, niezbędnej do podejmowania racjonalnych decyzji zapewniających realizację zadań,

- posiadanie określonego statusu prawnego umożliwiającego podejmowanie zobowiązań i ponoszenie prawnej odpowiedzialności za te zobowiązania z zachowaniem wglądu stopnia ryzyka,

- prowadzenie działalności w sposób stały".

Wskazując na podmiotowość rynku ochrony zdrowia, świadczą one usługi specyficzne, którymi są:

- $\quad$ profesjonalizm szczególnego rodzaju, wiążący się z wysokim ryzykiem i niepewnością pacjenta,

- $\quad$ ograniczona suwerenność pacjenta w sytuacji niemożliwości podjęcia przez niego stosownej decyzji,

- niepodzielność, czyli osobista sprzedaż usługi,

- niemożność jej magazynowania, stąd wymóg stałej gotowości na przyjęcie pacjenta,

- dostęp do usługi zdrowotnej regulowany nie przez mechanizmy rynkowe, ale na podstawie Konstytucji RP (Dz.U. Nr 78, poz. 483 z późn. $\mathrm{zm}$.).

Powyższe organizacje świadczą usługi zdrowotne zgodnie z zasadą rachunku ekonomicznego. Jednocześnie działają na rynku usług. Ich status prawny każe z jednej strony traktować je jako normalne przedsiębiorstwa zorientowane na zysk, z drugiej strony - jako 
jednostki niedochodowe. Często zmuszone są do działania sprzecznego z zasadami rachunku ekonomicznego. Stąd zarządzanie nimi i ich finansowanie wymaga innego spojrzenia i dalszych zmian.

\section{System ochrony zdrowia. Istota i funkcja}

Wzrastająca przedsiębiorczość, kształtowana w warunkach rynkowych, prowadząca do gruntownego przewartościowania organizacji, jest także widoczna w ochronie zdrowia. W odniesieniu do tego sektora można stosować również ogólną teorię sprawnego, to jest racjonalnego i skutecznego działania [14].

Funkcjonując w warunkach rynkowych, współczesne organizacje ochrony zdrowia nie są wolne od zmian. Zasadnym jest umożliwienie wzrostu partycypacji pracowniczej. Źródłem zmian jest wzrost aktywności i zaangażowania podwładnych w realizacji współczesnych zadań i rozwój organizacji.

Dynamizm w funkcjonowaniu współczesnej jednostki i społeczeństwa nie zminimalizował wartości zdrowia jako podstawowego czynnika determinującego efektywność podejmowania działań. Uzewnętrznia się więc wzrost wagi społecznej nauki jako dyscypliny naukowej, porządkującej wiedzę ludzką w odniesieniu do szerokiego i złożonego problemu, jakim jest zdrowie, jego utrzymanie (zachowanie) i opieka zdrowotna (profilaktyka), a nadto szeroko rozumiana polityka zdrowotna, w tym rehabilitacja i edukacja zdrowotna. Należy dodać, że zakres pojęciowy tej nauki wzbogaca tworzenie i powstawanie organizacji oraz ich rozwój. Winniśmy więc podjąć określone działania zapobiegawcze, które muszą koncentrować się na promowaniu zdrowego stylu życia i zachęcaniu do wkomponowania określonych zachowań zdrowotnych. Wyróżnia się pięć kryteriów umożliwiających określanie zachowań zdrowotnych; są to: poziom aktywności i świadomości, stosunek do zdrowia, konsekwencje zdrowotne, sytuacja zdrowotna, zachowania zdrowotne wynikające z roli i treści zachowania. Jednocześnie wskazuje to na złożoność i rolę w organizacjach ochrony zdrowia, a nadto na konieczność dalszej edukacji, to jest na racjonalne wykorzystanie zasobów ludzkich [15].

Przedmiotem „opieki zdrowotnej”, a też oglądu i badań naukowych, analizy i oceny jest całokształt zorganizowanych działań wykorzystujących stosowne urządzenia, normy prawne i bieżące regulacje oraz kompetentne instytucje, zorientowane na nową i szeroko rozumianą "ochronę zdrowia”. Należy dostrzec w niej systematyczne uporządkowanie, zbiór zadań naukowych, będących rezultatem działalności naukowej i szerokiej praktyki, nie tylko medycznej.

Określenie „opieka zdrowotna” sprowadza się zasadniczo do działalności usługowej, czyli świadczenia usług medycznych, jako konsekwencji potrzeb zdrowotnych.

Mając na względzie dobro jednostki ludzkiej i społeczeństwa, należy też umożliwić szeroką partycypację we współczesnych rozwiązaniach w tworzeniu nowej zdrowej jakości życia. Wielu autorów, konsekwencją powyższego, opowiada się za holistyczną koncepcją tego zagadnienia. Obejmuje ona zdrowie w sposób całościowy i kompletny. Podkreśla się bowiem, że owa wiedza społecznie niezwykle użyteczna, dyscyplina naukowa, umożliwia podjęcie skuteczniejszych niż dotąd działań na rzecz poprawy zdrowotności społeczeństwa. Jak się wydaje, obecnie jedynym rozwiązaniem jest konieczność innego społecznego i politycznego spojrzenia na zdrowie. W następstwie chodzi bowiem o rozszerzenie działań społecznych na rzecz zdrowia. Rezultatem winno być przeniesienie ciężaru gatunkowego walki o zdrowie z instytucji medycznych na instytucje życia społecznego i indywidualne zachowania jednostek.

W odniesieniu do różnych organizacji holistyczne podejście jest koniecznością w dobie przemian i szerszego oglądu zdrowia ludzkiego. Przedmiotem więc badań postmedycznych winny być - po pierwsze - takie problemy, jak: zdrowie i choroba, ochrona zdrowia, zapobieganie chorobom i prawo do życia, i - po drugie - problem nieprzestrzegania dyrektyw prozdrowotnego trybu życia, czyli zachowań przeciwstawnych. Powyższe problemy przemawiają za tym, że zdrowie jest jednym z filarów uznawanych powszechnie za istotną wartość. Jednocześnie warunkowane przez procesy życia społecznego, wymaga stałej kontroli i stosowania wielopłaszczyznowych działań. Wymaga m.in. działań fizycznych, psychicznych, społecznych i kulturowych wpływających na funkcjonowanie organizmu ludzkiego, a więc na zdrowie człowieka.

Przedmiotem badań dziedziny ochrony zdrowia winny być też koncepcje zdrowia, standardów opieki i profilaktyki zdrowotnej oraz uzależnień, nadto opieka medyczna nad uczniami i młodzieżą szkolną, jak też problemy patologii rodzinnej, zawodowej i czasu pozazawodowego, a również ich związek ze zdrowiem.

Warunkuje to miejsce i rolę usług zdrowotnych w życiu społeczeństwa jako całości oraz jednostki ludzkiej. Również wpływa na kształtowanie aktywności społeczno-zawodowych oraz uwzględnienie coraz pełniejszych oczekiwań społecznych. Owe usługi wskazują na konieczność ukształtowania pożądanego i odpowiednio skoordynowanego układu elementów, to jest instytucji świadczących dane usługi. Tenże układ, czyli ukształtowany zbiór odpowiednich organizacji, tworzący określoną całość, powinien być nastawiony na realizację pożądanych i w pełni zasadnych świadczeń i usług profilaktyczno-leczniczych oraz rehabilitacyj- 
nych. W szerokim ujęciu celem ma być nie tylko zabezpieczenie i utrzymanie, ale także poprawa stanu zdrowia jednostki i danej zbiorowości. Nie jest więc „celem życia, lecz środkiem do pełniejszego jego powodzenia" [16].

W miarę rozwoju nauk zwracających uwagę na pozamedyczne aspekty zdrowia powstawały warunki do redefinicji koncepcji zdrowia. W przeszłości było ono postrzegane jako stan przeciwny chorobom. W warunkach aktualnych zdrowie określa się jako stan pełnego i dobrego samopoczucia fizycznego, umysłowego i społecznego. W określeniu tym będą też wzajemne relacje między ciałem a umysłem danej jednostki ludzkiej, jako części określonej zbiorowości społecznej, a też pomiędzy instytucjami zdrowia i społeczeństwa jako całości. Ujmując ową kwestię, jednocześnie biorąc pod uwagę czynniki socjologiczne, psychologiczne i ekologiczne, należy stwierdzić, że „zdrowie jest dynamicznym stanem równowagi w sferze fizjologicznej, socjologicznej i ekologicznej funkcjonowania człowieka w świecie" [17]. Dobra kondycja zdrowotna umożliwia pełnienie wszelkich ról społecznych, a także prowadzenie produktywnego, sensownego i twórczego życia.

W obu określeniach - „system opieki zdrowotnej”, jak też „system zdrowotny” - podkreśla się systemowość, a zarazem celowość działań powoływanych organizacji (instytucji). System ten, jako specyficzny, jest bardzo złożony społecznie i biologicznie, w zasadzie jest nim działanie na rzecz opieki zdrowotnej. Obejmuje różnego rodzaju podmioty lecznicze i instytucje pomocnicze, a równocześnie nowe, niezbędne dla zaspokojenia potrzeb społecznych, działy i specjalności oraz jednostki lecznicze.

Czynnikami napędzającymi rozwój opieki zdrowotnej są ciągły postęp nauk medycznych i technicznych, a też zmiany warunków politycznych i nieustanne adaptowanie się do narastających i różnicujących się potrzeb zdrowotnych społeczeństwa. Należy przy tym zaznaczyć, że w pełni sprawny system opieki zdrowotnej nie istnieje. Jednakowoż powstający popyt na usługi zdrowotne i ich podaż umożliwia:

- zwiększenie nakładów na system opieki zdrowotnej,

- reglamentację świadczeń,

- zwiększenie efektywności.

Równocześnie zauważa się, że instytucje finansujące opiekę zdrowotną jako system marnotrawią środki. Generalnie, jako złożony społecznie i biologicznie układ, system umożliwia udzielanie szerokich i różnorodnych świadczeń zdrowotnych, mających na celu zapobieganie, diagnozowanie, leczenie i rehabilitację. W istocie sprowadza się to do rozróżnienia w omawianym systemie opieki podstawowej i specjalistycznej na poziomie niższym i wyższym. Waga szczeblowości or- ganizacyjnej dowodzi roli państwa w jego kształtowaniu się i funkcjonowaniu. Według Hibner „ochrona zdrowia to system, który w każdym państwie zajmuje się organizowaniem i finansowaniem medycyny naprawczej" [18]. Jednocześnie przypisuje mu się jeszcze inne, nie mniej ważne funkcje, m.in. pracodawcy, edukacyjno-wychowawcze, zarządcze, relatywne i polityczne.

Mając na celu sprawowanie opieki zdrowotnej, należy wskazać na dwa obszary odpowiedzialności władz publicznych, którymi są zdrowie publiczne i ochrona zdrowia. Rozróżnienie to nie zawsze jest dostatecznie ostre. Dlatego podstawowa funkcja ochrony zdrowia sprowadza się do zapewnienia działań mających zapobiec rozprzestrzenianiu się chorób i zapewnić właściwe warunki środowiskowe, a nadto zapobiec wypadkom i zabezpieczyć szybką pomocy w przypadku katastrof i kataklizmów oraz promować zdrowy styl życia. Mając na myśli wagę wszystkich działań, należy zapewnić dostęp do właściwej jakościowo opieki medycznej, jak też możliwość rozwoju nowoczesnego sytemu ochrony zdrowia oraz kadr czy nowych technologii oraz ustalić stosowne zasady finansowania. Chodzi tu o celowość i dostępność stosownej opieki zdrowotnej, a też o jej jakość i efektywność. Podkreśla się przy tym nastawienie na zabezpieczenie i dostarczenie możliwie pełnego zakresu świadczeń medycznych w ramach danej opieki dla całej populacji bez względu na wysokość dochodu, kulturę i miejsce zamieszkania. Przy tym chodzi o zapewnienie usług i świadczeń na możliwie najwyższym poziomie, stosownie do poziomu wiedzy, sztuki medycznej i zasad dobrej praktyki. Powyższe działanie cechuje się w praktyce wysoką produktywnością, racjonalnością i skutecznością, powinno zapewnić możliwie najlepsze wykorzystanie istniejących zasobów, czyli czynników produkcji.

Z punktu widzenia człowieka i całej społeczności system opieki zdrowotnej jest zorientowany na [19]:

- $\quad$ świadczenia opieki zdrowotnej rodzajowo zróżnicowanej,

- wsparcie ekonomiczne źródeł finansowania realizowanej opieki zdrowotnej,

- rozwój materialnych i osobowych zasobów opieki z zdrowotnej,

- tworzenie odpowiedniej struktury organizacyjnej opieki zdrowotnej, w tym podział na administrację centralną i terenową,

- $\quad$ szeroko rozumiane zarządzenie, umożliwiające nadzór, wsparcie regulacyjno-prawne i informacyjne.

Z rozwojem wiedzy i wzrostem świadomości podmiotowości obywatelskiej podejmowane były próby kształtowania systemów opieki zdrowotnej na miarę współczesnych potrzeb. Dostosowanie rzeczywistych 
systemów opieki zdrowotnej do oczekiwań społecznych jest trudne, niełatwo także sprostać tym oczekiwaniom. Niemniej wprowadzenie nowych rozwiązań pozwala na eliminowanie słabości systemu opieki zdrowotnej.

Realizując owe cele, często pojawia się przymus działania sprzecznego z klasycznym rachunkiem ekonomicznym. W konsekwencji system ochrony zdrowia oparty jest na opłatach pełnych, jak też niepełnych z tytułu świadczeń ponadstandardowych oraz na dotacjach z budżetu państwaina świadczeniach specjalistycznych. Owa wielość źródeł finansowania wymienionych jednostek wskazuje na ich bieżące i strategiczne funkcjonowanie oraz zachowanie się na rynku usług zdrowotnych. $\mathrm{Na}$ podstawie statusu prawnego danych jednostek są one traktowane z jednej strony jako przedsiębiorstwa zorientowane na zysk, a z drugiej natomiast - jako jednostki niedochodowe. Należy podkreślić, że funkcjonując w systemie opieki zdrowotnej i unormowaniach prawnych, nie mogą one odmówić udzielenia świadczeń zdrowotnych w sytuacjach zagrożenia życia i zdrowia.

$Z$ istoty rynkowej gospodarki wynika dalsza reforma podmiotów leczniczych. Pożądana jest większa swoboda podejmowania przez nie dalszych decyzji co do kierunku działania i zachowania na rynku usług zdrowotnych. Utrudnia to możliwość konkurencji pomiędzy tymi zakładami. Są one znacznie ograniczone również zachowaniem się usługobiorców usług medycznych. Nie mając dostatecznych informacji, a też napotykając na trudności w ich uzyskaniu, często rezygnują oni z leczenia się u danego usługodawcy.

Obecne warunki usług medycznych mogą utrudniać oddziaływanie mechanizmów rynkowych na właściwą alokację środków i przemieszczanie się pomiędzy podmiotami, to jest usługodawcami. Może to uniemożliwić także innowacyjność tych ostatnich.

Uogólniając, należy stwierdzić, że trudno jednocześnie ocenić sytuację na rynku usług medycznych. W kontekście okresu minionego dostrzega się wiele negatywnych zjawisk, m.in.: realny spadek dochodów różnych grup pracowników ochrony zdrowia i ukierunkowanie bazy leczniczej na opiekę stacjonarną (szpitalną) oraz przypisanie do rejonu, złe wykorzystanie czasu pracy, wieloetatowość, braki kadrowe, nierównomierność średniego obłożenia łóżek szpitalnych i czasu hospitalizacji oraz utrudnienia w dostępności do specjalistów. Zauważa się też w podmiocie leczniczym nadmiar specjalistów oraz niedobór wynikający z niewłaściwego ich motywowania. Szczególnie brakuje lekarzy specjalistów w podstawowej opiece zdrowotnej. Segment ten wymaga zdecydowanego wzmocnienia. Przemawiają za tym:

- rosnące oczekiwania społeczne co do jakości i skuteczności opieki zdrowotnej,
- $\quad$ stały rozwój technologii medycznych,

- potrzeba rozbudowy alternatywnych w stosunku do leczenia szpitalnego form na poziomie podstawowej opieki zdrowotnej.

Jednocześnie przemawia za tym wzrost liczebności osób starszych i zaawansowanych wiekowo (75-letnich i starszych) [20]. Uwagi te uzasadniają potrzebę zintensyfikowania procesów restrukturyzacji owych zakładów i świadczonych usług zdrowotnych w celu ich dostosowania do potrzeb społeczeństwa na rzecz poprawy efektywności wewnętrznej alokacji środków za pomocą racjonalnych systemów finansowania i motywowania stosownych reguł finansowych. Następuje również ich ciągła modyfikacja. Zmiany te sprowadzają się m.in. do:

- tworzenia szpitali,

- $\quad$ wdrożenia procesów cyfryzacji jednostek opieki zdrowotnej,

- łączenia się zakładów publicznych w wyniku przejęć,

- $\quad$ przekształcania publicznych zakładów w spółki prawa handlowego,

- $\quad$ wzrostu liczby lekarzy w podstawowej opiece zdrowotnej zgodnie z ich specjalnością zawodową,

- $\quad$ wzrostu liczby pielęgniarek cechujących się odpowiednimi umiejętnościami i pożądaną etyką,

- wzrostu liczby studentów uniwersytetów medycznych zgodnie z zapotrzebowaniem rynku usług zdrowotnych na określone specjalizacje,

- $\quad$ stworzenia takich warunków pracy i systemu wynagrodzeń, aby zatrzymać wykształconą kadrę medyczną w kraju.

Przy tym należy podkreślić, że pożądana jest równocześnie zmiana modelu motywacyjnego w całej populacji i służbie zdrowia. W wyniku działania zorientowanego na kreowanie i realizację celów i zadań, a także programowania zleceniodawców i odbiorców usług medycznych powstaje konieczność zainteresowania się nie tylko poziomem usług, ale też wzrostem efektywności działania. Temu służyć winny motywujące kontakty menadżerskie. Niezbędne są działania promocyjne i szkoleniowe. Konieczne będzie wprowadzenie systemu usług medycznych, wykorzystującego różne formy grantów, a też partycypowanie w rynku pełnopłatnych usług i szukanie nowych środków finansowania dalszej działalności.

Pożądana też byłaby analiza zasobów rzeczowych, finansowych i osobowych. Dokonujące się w ostatnich latach przemiany jednoznacznie wskazują na konieczność samofinansowania na podstawie właściwie prowadzonych rachunków kosztów. 


\section{Zakończenie}

Przeobrażenia dokonujące się na przestrzeni ostatnich lat w kraju wymusiły zmianę przepisów prawnych i statusu funkcjonujących na rynku usług medycznych zakładów opieki zdrowotnej. Uzasadniało to potrzebę zmian w systemie ochrony zdrowia w miarę postępujących transformacji życia społeczeństwa i jednostki ludzkiej. Większe usamodzielnienie i urynkowienie zakładów opieki zdrowotnej winny korzystnie wpłynąć na wzrost gospodarowania, to jest na racjonalne wykorzystanie posiadanych zasobów rzeczowych, finansowych i ludzkich, a też na zwiększenie dochodów zakładów opieki zdrowotnej poprzez zwiększoną sprzedaż usług oraz darowizny i sponsoring. Dotychczasowe zmiany wskazują na możliwość podporządkowania się jednostek służby zdrowia określonym regułom gry rynkowej. Dyskusja na temat sektora ochrony zdrowia, w tym nad rolą, miejscem i działaniem zakładów opieki zdrowotnej w warunkach zachodzących zmian w społeczeństwie, gospodarce i państwie, winna oscylować wokół nowych zasad organizacyjnych i ekonomicznych, umożliwiających połączenie ducha przedsiębiorczości za społeczną wrażliwością. Istnieje więc potrzeba nowego sposobu zarządzania tymi jednostkami. Dalsze zmiany w zarządzaniu nimi winny sprzyjać próbom godzenia efektywności ekonomicznej z efektywnością społeczną, przynajmniej w zakresie standardowych świadczeń zdrowotnych.

\section{Piśmiennictwo}

1. Dobrzański K. Przedsiębiorczość w restrukturyzacji narzędzi zmian w funkcjonowaniu przedsiębiorstwa. W: Zimniewicz $\mathrm{K}$ (red.). Instrumenty zarządzania w współczesnym przedsiębiorstwie. Analiza krytyczna. Poznań: Wyd. Akademii Ekonomicznej; 2006. 133.

2. Skorupka S, Auderska H, Łempicka Z (red.). Mały słownik języka polskiego. Warszawa: PWN; 1968. 1020.

3. Mikołajczyk Z. Zarządzanie zmianami w przedsiębiorstwie. Organizacja i Kierowanie. 1993; 3: 3.

4. Dobrzański K. Dywagacja nad naturą i procesem badań w nauce o zdrowiu publicznym. W: Głowacka MD (red.). Społeczne konteksty edukacji zdrowotnej. Poznań: Wyd. Wyższej Szkoły Komunikacji i Zarządzania; 2006. 9-18.

5. Webber R. Zasady zarządzania organizacjami. Warszawa: PWE; 1996. 393.

6. Majchrzak J. Przekształcenia polskich przedsiębiorstw w świetle teorii zmian organizacyjnych. Poznań: Wyd. Akademii Ekonomicznej; 2001. 43.

7. Masłyk-Musiał E. Zarządzanie zmianami w firmie. Warszawa: CIM; 1995. 42.

8. Bratnicki M. Zarządzanie zmianami w przedsiębiorstwie. Katowice: Wyd. Akademii Ekonomicznej; 1997. 9-11.
9. Grochowski M. Rejonizacja służby zdrowia a dostępność usług medycznych. Warszawa: Wyd. Uniwersytetu Warszawskiego; 1988. 47.

10. Janku Z, Spławska E. Prawne podstawy funkcjonowania zakładu opieki zdrowotnej. W: Głowacka MD (red.). Zarządzanie zakładem opieki zdrowotnej. Wybrane konteksty teoretyczno-praktyczne. Poznań: Wyd. Termedia; 2004. 18.

11. Obwieszczenie Marszałka Sejmu Rzeczypospolitej Polskiej z dnia 25 kwietnia 2002 r. w sprawie ogłoszenia jednolitego tekstu ustawy o zamówieniach publicznych. Dz.U. 2002 r. $\mathrm{Nr} 72$, poz. 664 ze zm.

12. Jończyk J. Zarządzanie zasobami ludzkimi w zakładach opieki zdrowotnej. Warszawa: Wyd. Difin; 2008. 94.

13. Galicki J. Zarządzanie dynamiczne w zakładach opieki zdrowotnej. W: Głowacka MD, Mojs E (red.). Szanse i bariery w ochronie zdrowia. Wybrane aspekty organizacyjno-prawne. Poznań: Wyd. Nauk. Uniwersytetu Medycznego; 2008. 40-41.

14. Prakseologia. W: Encyklopedia powszechna. Warszawa: PWN; 1975. 681.

15. Sęk H. Zdrowie behawioralne. W: Strelau J (red.). Psychologia. Podręcznik akademicki. Jednostka w społeczeństwie i elementy psychologii stosowanej. Tom III. Gdańsk: Gdańskie Wyd. Psychologii Stosowanej; 2000. 533-553.

16. Rudawska J. Marketing w nowoczesnej opiece zdrowotnej. Szczecin: Wyd. Nauk. Uniwersytetu Szczecińskiego; 2005. 15.

17. Niźnik J. W poszukiwaniu racjonalnego systemu finansowania ochrony zdrowia. Bydgoszcz - Kraków: Oficyna Wydawnicza Branta; 2004. 18.

18. Hibner E. Zarządzanie w systemie ochrony zdrowia. Łódź: Wyd. Wyższa Szkoła Humanistyczno-Ekonomiczna; 2003. 70.

19. Głowacka MD, Mojs E (red.). Postulaty Światowej Organizacji Zdrowia. Profesjonalne zarządzanie kadrami w zakładach opieki zdrowotnej. Warszawa: Wolters Kluwer; 2010. 109.

20. Dobrzański K. Funkcjonowanie ludzi starszych w warunkach lokalnych. Przyczynek do problemu. W: Konieczna-Woźniak R (red.). Dorosłość wobec starości. Oczekiwania - radości - dylematy. Poznań: Wyd. Uniwersytetu im. Adama Mickiewicza; 2008. 47-58.

Artykuł przyjęty do redakcji: 04.07.2016

Artykuł przyjęty do publikacji: 25.08.2016

Źródło finansowania: Praca nie jest finansowana z żadnego źródła. Konflikt interesów: Autor deklaruje brak konfliktu interesów.

Adres do korespondencji:

Kazimierz Dobrzański

os. Powstań Narodowych 15/5

61-214 Poznań

tel.: 618791467

e-mail: kazimierzdobrzanski@wp.pl

Wyższa Szkoła Zarządzania i Bankowości w Poznaniu emerytowany pracownik Katedry Systemów i Technik Zarządzania Uniwersytet Ekonomiczny w Poznaniu 